\title{
A Critical Analysis of Interfaith Dialogue Movement in Pakistan and its Future Prospects
}

\author{
Dr. Riaz Ahmad Saeed \\ Lecturer, Department of Islamic Studies, NUML, Islamabad \\ Email: riazussaeed@gmail.com
}

\begin{abstract}
:
In modern ages, the nations, faiths and communities are more in need of better relationship, tolerance and peace from any other phase of the human history. Therefore, interfaith dialogue has become the most significant activity in this age of the conflict and clash. Due to its importance, many religious, non-religious even political parties have deeply involved in it. In Pakistani perspective, the Christian Study Center, Rawalpindi, has a historical role to promote Muslim-Christian Dialogue. The Christian Study Center, Rawalpindi, one of the major dialogue institutes in Pakistan has been busy in holding interfaith dialogue, meetings, workshops, seminars and conferences at national and international levels for the past 50 years. Definitely, this activity has some kinds of positive and negative impacts on Pakistani society. Therefore, Muslim and Christians have shown their concerns about modern interfaith dialogue movement for various reasons. In such a situation, the question arises whether these activities have any future hopes and impacts on the society and what are the chances of success taking into account their usual directions? What do scholars think about the future of interreligious dialogue in Pakistan? In this study, efforts are being made to evaluate the interfaith dialogue movement in Pakistan from futuristic perspective in the light of Muslim-Christian scholarly views. The analytical and critical research methodology was adopted in this study with qualitative approach. For data collection libraries, websites, journals, interviews and discussion methods were used.
\end{abstract}

Keywords: Future Hopes, Interfaith Dialogue, Pakistani Context, Scholarly Views, Analysis

Interfaith dialogue has become one of the most throbbing issues cum activities in the current global socio-political scenario, especially from the Muslim and Christian perspectives. Muslims and Christians both claim to be the pioneers and experts of interfaith dialogue and use it in their own style and strategy for their Daw'ah and missions. Moreover, some secular groups from both sides are using interfaith activity for fame, even as anti-religious movement. As a result, many organizations, individuals and some political parties have got involved in this interfaith activity. In Pakistan, there are many 
churches, Christian and Muslim institutes and individuals who are actively involved in this activity. Some political parties also show keen interest in this activity. All over the world, many countries, in order to make their image better, officially promote the interreligious dialogue. For example, many international interfaith dialogue conferences are arranged by USA, UK and Saudi Arabia. Once Dr. Mahmud Ahmad Ghazi ${ }^{1}$, a leading Muslim scholar of the $20^{\text {th }}$ century, said about dialogue:

"It is a fact that the Muslim nation always welcomes cooperation and conduction of dialogue between religions and civilizations. The Qura'n calls other religions to act jointly to promote common values and spiritual release of the human beings." 2

This statement addresses the main objectives and goals of interfaith dialogue. As we know it very well, Dr. Ghazi attended many interfaith dialogue conferences at national and international levels, but he has some concerns over the nature of the dialogues. He once said in a lecture during interfaith dialogue, "This dialogue can be used positively, as well as, negatively, because the nature of this dialogue is socio-political and western political leaders use it for their own benefits." 3 Furthermore, Muslim scholars have criticized the political use of interfaith dialogue as well as some modern scholars have also shown their concerns on current movement of interfaith dialogue. Here, a contemporary leading Muslim scholar, Sheikh Yusuf al-Qardhāvī4, has openly said about the end result of these conferences in a different way:

"Brothers, there is a problem with our dialogue with these people

(Liberal and secular Christians) ... Give me one practical thing that these conferences have achieved for the benefit of the Islamic nation. I cannot find a single thing."

But if there is no complete agreement, then there is no complete disagreement on this issue as well. In other words, partially, it can be agreed because the end result of these dialogue conferences is not very bright and it can also be partially disagreed in the sense that the involvement in interfaith dialogue opens the door for peaceful mutual understanding and peace process between faiths and communities. However, the most important issue is that this dialogue should be kept away from political involvement of any kind. Therefore, the concern regarding political involvement is true. The Muslim scholars of 
international repute, who are considered modern in their approach, even they do not like political interference in this interfaith dialogue activity. They show their concerns at political involvement in the interreligious dialogue. One of the most powerful voices in this regard is of Prof. Dr. Mustafa Marāghi, the rector of AlAzhar University Cairo, Egypt. He raised this issue in an International conference of World Faith for Interfaith Dialogue. He said, "Any political involvement in the process of interfaith dialogue movement would ruin all." Therefore, it is in the benefit of this dialogue that it should be kept away from any kind of political involvement.

Moreover, every dialogue movement and activity has its own objectives and agenda, some of them are religious and some of them are political.

The question we want to focus on is that do these activities have any hope in future in Pakistan? What do Muslim and Christian scholars think about this activity? Here, we shall evaluate the religious, social and political impacts in Pakistani context. In this important and live study, we will examine the future hopes of modern Muslim Christian dialogue movement in the context of Pakistan, with special reference to the Christian Study Center, Rawalpindi and in the light of Muslim-Christian scholarly views. Hopefully, this study will introduce many new dimensions of dialogue and will help out the scholars and researchers to improve the quality and quantity of the dialogue in Pakistan specially and in all over the world generally.

\subsection{Future of Interfaith Dialogue in Pakistan:}

It has been noticed during this study that some people, especially those having links with the CSC, warmly agree to hold dialogue, but most of the Muslim scholars disagree and they have some reservations and doubts about this kind of dialogue. Some of the Christian scholars and participants are also doubtful about this dialogue, thus raise some important points for the 
effectiveness of this dialogue movement. The most interesting thing is that the majority of Muslim scholars agree to Muslim-Christian dialogue in Pakistan and accept its importance but they disagree to the present movement of dialogue. One of the leading Pakistani Islamic scholars, Mufti Muhammad Taq Usmān̄̄ ${ }^{-}$, commented:

"Dialogue is very necessary and important between Muslims and Christians of Pakistan for Islamic Daw'ah communication, understanding, respect and peaceful coexistence but the present dialogue does not fulfil these requirements because this is a social and political dialogue." 8

Even some impartial Christian scholars do not agree to this kind of dialogue. As we read in an interview of a renowned Pakistani priest: "We do not like and appreciate the present interfaith dialogue because there is no discussion of theology in this dialogue and this is a liberal and social dialogue." 9 The main reason of controversy behind this dialogue is that every individual and party is involved in this dialogue for its own interest and objective. It has been found in a study, "Many groups of scholars, institutes, organizations and even governments are involved in it. Everyone has its own objectives and agenda; even many secular, liberal and political parties are also promoting this dialogue. ${ }^{, 10}$ We can see that there are real reasons behind ineffectiveness of this dialogue. Here, we would like to describe the future hopes of this dialogue as well as some important reasons for its prospective failure and ineffectiveness.

\section{1. Bright Future of Interfaith Dialogue in Pakistan :}

Some of the Muslim and Christian scholars and social activists claim that the modern interfaith dialogue is going in the right direction and its future is very bright in Pakistan. The foremost are the scholars of the CSC and its administration. The administration and leaders of the Christian Study Center 
Rawalpindi are satisfied with its future. Mr. Mehbûb $S a d \bar{a}^{11}$, the director of the CSC, stated in an interview, "I am hopeful that the direction of the Christian Study Center Rawalpindi dialogue is right and the future of the MuslimChristian Dialogue is very bright in Pakistan." ${ }^{12} \mathrm{He}$ further explained: "A happy society can be developed if all the issues are solved with commitment. If we support peace bridges, revise the education curriculum and syllabus, revise the media policy and work together to build up a good and liberal society, the future of the dialogue are very bright and successful in Pakistan." ${ }^{13}$ Another important personality of the CSC is Madam Rom $\square$ na Bash $\square r$, who is the program coordinator of the Center. She said in an interview:

"The Christian Study Center dialogue activities have a lot of religious, social and political impacts on Christian-Muslim communities of Pakistan. The social harmony increases on religious basis. The numbers of our contributors are increasing day by day. On these bases I can say that the future of MuslimChristian dialogue in Pakistan is very good and bright." 14 Another important Christian scholar, dialogue expert and the main resource person of the Christian Study Center Rawalpindi, Fr. James Channan $\mathrm{OP}^{15}$, also agrees with this thinking that the future of the present dialogue is bright. He said in an interview, "We see a good improvement in interfaith dialogue activities in Pakistan. Nobody talked and listened to such dialogue, thirty years ago, but now the dialogue culture is developing. Thus, I can see the dialogue future is very good." 16

Some people do not agree with the direction and issues of the CSC dialogue, but they are hopeful that the future of Muslim-Christian dialogue in Pakistan is bright. An active person in Christian-Muslim relations and dialogue, Qäri Abdul Qadìr Khämüsh, said in an interview, "I do not totally agree to the approaches, issues and methodology of the Christian Study Center's dialogue, 
but I am hopeful that the future of the Muslim-Christian dialogue in Pakistan is very good and bright." ${ }^{17}$ In fact, the actual situation of dialogue in Pakistan is not so good because the mainstream Muslim scholars and public do not like the present interfaith dialogue because they show their reservations and doubts. Majority of them do not participate in such dialogue. What is very interesting and strange regarding interfaith dialogue is that the majority of the Muslim scholars, even the representatives of different sects and school of thoughts, want to promote it but they take the present interfaith dialogue as a conspiracy against Islam and Muslims. The future of the present dialogue in Pakistan can be bright if its basic rules and regulations, issues and approaches are revised.

\subsection{Nominal Future of Dialogue Movement in Pakistan:}

According to a reasonable majority of the Muslim scholars, the future of the Christian Study Center's dialogue is nominal because the approaches, issues, methodology and scholarship of the Christian study Center is also nominal and mainstream Muslim scholars and public do not have any interest in this kind of dialogue. Even some modern Muslim scholars also demand to change and revise the methodology of this dialogue. Dr. Muhammad Modassir $\mathrm{Ali}^{18}$ stated in a discussion on interfaith dialogue:

"If we want to establish a fruitful dialogue between Muslims and Christians Communities of Pakistan, we should completely revise the present direction and strategy and approach of the dialogue because it does not match with the temperament and interests of Pakistani society." 19

Most of the Muslim scholars of Pakistan agree on this point that the future of this interfaith dialogue movement is nominal rather than bright. According to Dr. Muhammad $\mathrm{Akram}^{20}$, "Although the future of this dialogue is nominal and the direction and methodology is also not right but we should 
participate in this dialogue because in this way we can deliver our Islamic message to them and understand their point of view about Islam.. ${ }^{21}$ A renowned professor of comparative religion at the university of Punjab, Lahore, Prof. Dr. Ghulam Ali khan, said, "The future of modern interfaith dialogue is not bright but nominal and weak because their vision is not clear, their issues are sociopolitical rather than interreligious, as well as, their methodology towards dialogue is controversial. ${ }^{, 22}$ Prof. Dr. Imtiąz Zafar, who practically participated in the CSC dialogue stated, "The future of the modern Muslim-Christian dialogue in Pakistan is not bright but nominal due to some academic reasons and nonacademic reasons. ${ }^{, 23}$ Even their resource persons and contributors do not agree with the idea of the bright future of this dialogue. Ex-chairman of Islamic ideology Council and IRI, Prof. Dr. Khalid Mas'ud ${ }^{24}$ said, "The future of the modern interfaith dialogue movement is nominal due to our environment and some other political and religious reasons. ${ }^{, 25}$ Dr. Modassir Ali further said, "The future of the present Muslim-Christian dialogue in Pakistan is nominal but if we revise its approaches, issues and methodology, it may become a fruitful activity for Pakistani interreligious community." ${ }^{26}$ Some social activists have deep interest in this interfaith activity. A social activist and an active resource person of the CSC, Madam Samina Imtiā, stated about the future hopes of interfaith dialogue in this way, "The future of the CSC's interfaith dialogue is nominal in Pakistan due to different reasons." 27

The future of the Christian Study Center's dialogue seems nominal due to the national, political, social and religious environment and some other academic and non-academic reasons. Another important reason of the weakness of this dialogue is the social direction and controversial scholarship (contributors) of this dialogue. If we want to establish fruitful dialogue 
activities, we need to accept the valuable suggestions of the Muslim scholars and try to remove their reservations.

\subsection{Weak Future of interreligious Dialogue Movement in Pakistani Society:}

A number of Pakistani Muslim scholars, especially the traditional Muslim scholars ('Ulamā) think that the future of the present Muslim-Christian dialogue is weak in Pakistan due to certain reasons. There are some misunderstandings which may damage the future of the dialogue. Shäbid Habib said:

"There are some misunderstandings regarding dialogue in Pakistan. There is a huge gap between followers of Islam and others. Many critics viewed the situation from different angles. They have highlighted some problems which create difficulties to carry out dialogue in Pakistan."28

The editor of 'Focus Magazine' describes these reasons of ineffectiveness of the dialogue: one of them is misunderstanding about interfaith dialogue. He says, "It means that the dialogue was obstructed because of misunderstanding about its very nature. Both Muslims and Christians are afraid of being converted. Christians are worried about their survival so they do not go for dialogue." 29 Even some modern and famous scholars do not agree with the current direction, approach and methodology of the Muslim-Christian dialogue. According to Prof. Dr. Gbuläm Ali Khan:

"The future of the present Muslim-Christian dialogue is not bright but nominal and weak because their vision is not clear and their direction and methodology are not suitable for Islamic teachings about dialogue and Pakistani Muslim society. $" 30$ 
According to many dialogue experts, the future of this dialogue is weak and the participation of the Muslim scholars and public is also nominal and feeble. A well-known Islamic scholar of comparative religions and dialogue expert, Dr. Safir Akhtar" ${ }^{31}$, said in a letter regarding this dialogue activity, "The future of the present dialogue is weak due to some reasons." He further said, "The nature of this dialogue is social, rather than religious and the participation of Muslims (public as well as scholars) is also normal." ${ }^{32}$ Even the scholars and resource persons of the CSC are not satisfied with the future of this interfaith dialogue. A well-known resource person of the CSC, Dr. Naim Mushtāq ${ }^{33}$, says, "The future of this dialogue is very weak because the contributors of the CSC do not know what interfaith dialogue is? And even they do not know about their own religion or about Islam. Majority of them are social activists and belong to different NGOs." ${ }^{34}$ He further said, "According to my thinking, they do not have any clear vision of dialogue rather, some of them are destroying the dialogue and spreading confusion about Muslim-Christian dialogue in Pakistan.,35 Another famous resource person of the Christian Study Center, Rawalpindi as well as an active social activist, Käri Jāvid, stated in an interview with a note of difference, "Although, the future and impacts of the CSC dialogue is not so bright but it is a little effort in a tense and extreme environment of Pakistan for interfaith peace, harmony and peaceful co-existence. ${ }^{36}$ According to some traditional Muslim scholars, the modern interfaith dialogue movement is promoted by the Western powers and thus has no future in Pakistan with same practice and approach. Dr. Tähir Mahmud, principal of Jämia Salfia Islamabad, said in an interview, "Interfaith dialogue is a good activity but it is assumed the present dialogue movement is launched and promoted by the West, so it has no good future and even cannot play a positive role to make Muslim-Christian relations better in Pakistani context." ${ }^{37}$ It is observed from this dialogue that 
normally, Christians are the hosts of this dialogue and they enforce their policies, especially foreign agenda in Pakistan. Another most prominent Muslim scholar Dr. Alvi analyses the situation as:

"The topics of the dialogue are those which the European countries set to influence the Muslim states and societies, such as freedom of women, human rights, rights of minorities, secularization and enforcement of Shar $\square$ 'ah, etc. In these meetings, the behavior of Christians is aggressive while that of the Muslims is defensive and apologetic.",38

Due to these issues, some of the Muslims scholars avoid to participate in this kind of dialogue because they think these are western promoted activities and Christian are more organized and established to get benefit from them. Mr. Khalid Jamil, director publications, Karachi University said, "We should not have dialogue with these kinds of Christians because the western powers are supporting them and they are well organized in their economic, political and defensive systems. The dialogue should be based on equality. The dialogue is useless if we do not reach up to their level of growth, advancement and development." 39 Controversial issues are discussed in this dialogue and sometimes the participants of dialogue raise question on the Islamic identity of Pakistan. Domenic Mughal, a renowned resource person and ex-director of the CSC writes in a book, "The state must repeal all discriminatory laws such as, the Hudüd Ordinance ${ }^{40}$, the Blasphemy Law, Diyat (Blood Money), the Law of Qisäs, the Law of Evidence and the separate electorate. The state must give basic rights to the minorities." ${ }^{41}$ The Christians should avoid controversial issues and demands if they want a fruitful and constructive dialogue between Muslims and Christians of Pakistan. These controversial activities damage the cause of 
interfaith dialogue and leave question marks on the validity and importance of the dialogue in Pakistani society.

It is noticed that the most important reason to join this dialogical activity from the Muslim side is Islamic $D a$ 'wah. A renowned Muslim dialogue expert and scholar, Dr. Muhammad Atäullah Siddīì said, "Muslim participation in dialogue needs to be seen first in a theological perspective and secondly as an encounter with Christianity in the contemporary situation." ${ }^{42}$ So for that purpose, Muslims have expectation of Da'wah and mutual understanding from this dialogue. But unfortunately due to some reasons, this kind of dialogue is eliminated under the banner of modern socio-political dialogue. Hence, some Muslim scholars have shown their reservation towards this kind of dialogue; because they think this dialogue minimizes the option of Islamic Da'wah and most of the time, the participants' compromise over it. A renowned professor of Islamic studies at the University of Punjab, Lahore, Prof. Dr. Muhammad Hammäd Lakhvì says:

"The very sad aspect of this dialogue for Muslims is that it is limiting, decreasing and sometimes harming Islamic $D a$ 'wah in generally all over the world, especially, in Islamic Republic of Pakistan. Of course, we strongly agree with interfaith dialogue but disagree with these sociopolitical sittings and statements in the name of interfaith dialogue.",43

I was surprised to know that the University Department of Islamic studies was going to initiate a research study on that topic to recognize its merits, demerits, challenges and opportunities and later on in 2012, it was practically lunched and finally completed in 2016 entitled, "Islamic Da'wah in 
the context of Global Interfaith Dialogue Scenario: Challenges and opportunities." 44

In addition, as I mentioned earlier, the missionary activities under the umbrella of interfaith dialogue have been a point of concern for Muslim scholars. There are many evidences of this fact. It is said from Qāzī Mu'iz ud Din, an expert of dialogue activities: "He himself arranged many conferences and judged them thoroughly. He reached the conclusion that dialogue is a part of Christian missions and in Pakistan those churches and Christians are working for their cause and receive funds from the foreign countries. These people make a hole in the boat in which they are voyaging." ${ }^{45}$ Most of the dialogue activities in Muslim countries increase the Christian missionary activities. An international research journal, Missiology, reveals the inside of this story, "Dialogue in its very nature is a missionary activity. It is, to Catholic Church, a means to expand the mission of Christ and lead the people to eternal salvation by converting them to Christianity." 46 The appreciation of Pop Johan Paul for interfaith dialogue for missions is also a reason of Muslims' concerns. He said in an international interfaith dialogue conference, "I am glad to see the active participation of Franciscan community in interreligious dialogue with a new spirit because this dialogue is an important part of the Church mission for the Universalization of Christianity." 47 For that purpose, Muslim scholars show their concerns for interfaith dialogue, for its methodology, issues, status and future. Prof. Dr. Khalid $A l v \bar{v}$, a well-known Pakistani scholar said, "It is a new tactic, which is used to confuse the Muslims in interreligious dialogue. In diplomatic language, it is called engagement." 48 Therefore, these kinds of reservations compel us to rethink about the modern interfaith dialogue movement. It is the duty of the representatives of this dialogue to give suitable answer to these reservations. 
Some Christian scholars also do not see a bright future of dialogue in Pakistan. They show their concerns and reservations for the dialogues due to some reasons. A renowned Christian scholar, Johan Slomp, says:

"There are some deeper political and religious reasons embedded in the Islamic Culture (for the failure of dialogue). 1- Christian community was not ready because it has Hindu background. 2-Muslims never accepted the non-Muslim in Pakistan as an equal partner. 3- The Pakistani Christian Church has no (scholarly) people for the dialogue at that level. 4- (For Muslim concern), Muslims take dialogue as dangerous to their faith. Pakistani people view missions are enemy to Islam." 49

A renowned supporter of interfaith dialogue also accepts some deficiencies within dialogue. Jane Smith articulates in her book, "Nonetheless, not all interfaith experiences turn out well. Those who are engaged in the lengthy experience in dialogue understand that there are traps into which even the most ardent advocates of interfaith exchange may fall, and problems that must be addressed if real progress is to take place in mutual understanding." 50 This is also like a reservation when someone says that we are going to search for common grounds in different faiths because it is difficult and sometimes impossible. Understanding is a better word for dialogue interpretation. David Lochhead, a Christian scholar, says:

"Rather than defining dialogue as a search for agreement, it would be more helpful to define dialogue as a search for understanding. To understand another tradition, I do not have to agree with its precepts. I do not have to create 'common ground' in order to proceed." 
In addition, another prominent Christian scholar and theologian, Terry Muck, criticizes the current dialogue, "In situations where hostility is not present, where the mutual exclusions of truth are assumed, where commitment is allowed, and where agreement is not the minimal expectation, interreligious dialogue is not just allowed, but I would suggest the world situation demands it." ${ }^{52}$ It is another objection from Christians that the interfaith dialogue is conducted in an apologetic way, not in the sense of understanding and defense of religion. A renowned Christian scholar, Jason Barker, writes:

"Mostly religious communities have leaders who are responsible for defining what is considered orthodox doctrine. These doctrines frequently contradict the doctrines held by other religious communities. Thus, for interreligious dialogue to be effective, participants must be allowed to make doctrinal claims, to temperately criticize the doctrinal claims of others, and to defend their doctrinal claims when criticized. The caution is that such criticism and defense must be done in a respectful, non-aggressive manner."

These are the views and discussions about future hopes of the MuslimChristian dialogue in Pakistan with special reference to Christian Study Center Rawalpindi, which at the moment is not good, bright and desirable. After a long interaction with the CSC as well as a good number of interviews and discussions with the CSC administrators, resource persons and Muslim-Christian scholars and 'Ulemā from Islamabad to Karachi, we found that the hope for future of dialogue is of intermediate level, not bright. It is stated on behalf of this study that it will remain nominal and weak until the issues, approaches, methodology and agenda of the dialogue are revised with wider consultancy with Muslims and Christian's scholars of Pakistan. Here, I completely agree with Dr. Muhammad Modassir Ali's views: 
"If we want to establish a fruitful dialogue between Muslim and Christian Communities of Pakistan, we should completely revise the present direction, strategy, issues and approaches of this dialogue because it does not match with the temperament and interests of Pakistani society." 54

We also cannot ignore the concerns of Dr. Mutiullah Bäjawab regarding interfaith dialogue and Islamic Da'wah. He concludes in his $\mathrm{PhD}$ thesis, "If we want to initiate a meaningful interfaith dialogue which meets the standard, goals and objectives of the Islamic Da'wah, we should revisit our policy about contemporary interfaith dialogue, because sometimes it becomes a tool to eliminate or damage Da'wah." ${ }^{55}$ Here, he shows his concern that the modern interfaith dialogue marginalizes the scope of Islamic Daw'ah in Pakistan, especially all over the world.

Here, I feel necessary to quote a Christian dialogue expert, Paul Griffith, whose suggestions should be considered as a food for thought for meaningful interfaith dialogue, "The (Interfaith Dialogue) participants should be the representative intellectuals of a religious community who typically engage, among other things, in the formulation and defense of sentences expressing doctrines of the community." knowledge, learning and responsibilities. An important question which is raised by a renowned Muslim scholar, Prof. Dr. Muhammad Yusuf al-Qaradhāwin, "We recognize Christianity (their religion, their Prophet and their book) but they (Christians) do not recognize us (our Religion, our Book and our Prophet)." ${ }^{57}$ It is interesting that many Christians orthodox have lack of interest in dialogue because there is no conversion in this dialogue. A Bulgarian scholar, Millen Markov, argues: 
"According to the Christian understanding, inter-religious dialog verifies the abilities of the opponent to formulate in a non-contradictory way doctrines of his religion. Such criterion of verification is restrictive, as far as it excludes from the discussion field dimensions coming from the personal experience. They actually constitute the palpability of the religious faith. The theological discourses do not have hidden agenda of conversion of the opponent. They demonstrates that his arguments do not bear out verification of reason." $" 58$

Although, Muslim scholars appreciate and participate in all kinds of interfaith dialogue activities, but they continuously show their concerns and reservations on this type of dialogue for its misuse by secular lobby, extremist religious leaders and political figures. One of the most important and comprehensive reservation on these activities is of a reputed Pakistani scholar of comparative religion and a warm participant of interfaith dialogue, Prof. Dr. Miraj al-Islam Zia;

"Interfaith dialogue has evolved over the years and has been influenced to some degree by missionary activities and political interests of Christians. The reason for holding such dialogue should be according to the teachings of Islam. Qur'an and Hadith have produced some specific guidance to Muslims on how to conduct their affairs with Christians, Jews and other non-Muslims. On the contrary, the New Testament contains no such details with regard to Muslims and therefore, it is hard to clearly identify Christian objectives in interreligious dialogue. ${ }^{, 59}$ 
Here, as a point of objection, I have described the truth why I feel that this dialogue has misuses and one of them is the missionary activities from the Christian community. It is also a fact that the open use of this dialogue forum is also alarming, however if Muslims object to missionary activities, then Christian scholars can also raise the same question. Thus, I think we cannot openly use this forum for that kind of pure religious activities under the umbrella of interfaith dialogue. I believe that the positive discussion and thoughtful sharing should be carried on to understand the faiths and religions of each other.

In addition, I believe we should at least carry on this dialogue with a positive spirit and try our best to make it useful for the common good of interfaith relationship and peaceful coexistence. Although Muslim scholars show their apprehensions regarding this dialogue, we should not stop this interfaith activity. Rather we should attempt to do it in a better way and create a better environment for interfaith tolerance and peaceful coexistence. Essentially, it is the duty of the leaders and experts of both communities and we should collectively work together to resolve these hurdles and issues which are damaging this interfaith activity. Here, Mr. Sāqib Akbar's suggestion cannot be ignored. He articulates, "According to our opinion, instead of all clashes and complaints all partners would reach on the conclusion that we should use all capabilities and efforts to attain good relationship."60 It is a valid and reasonable suggestion from a Muslim scholar. We should own it in its real sprit.

Moreover, it is perceived that interfaith dialogue activity in Pakistan will remain weak until we revise the whole infrastructure and foundations of this dialogue with broader consultancy of Muslim and Christian scholars of Pakistan. The core interreligious issues should be discussed here with its real spirit for the promotion of good interfaith understanding, better mutual 
cooperation, peaceful coexistence, interreligious respect and tolerance as well as social and interfaith harmony. This is the only way to move forward and it presents itself as an ultimate choice so that the communities of different faiths can survive in the diverse global village of the world. Otherwise, these dialogue activities are no more than beautiful academic engagements to cheat ourselves publically, as well as a way to earn fame and wealth.

\section{Conclusion:}

It is concluded from the above discussion that Islamic Republic of Pakistan is one of the countries, where interfaith dialogue activities are entertained at state level. As well as, many other institutes are involved to hold interfaith dialogue activities at national level and one of the most prominent pioneer of them, is the Christian Study Center, Rawalpindi, Pakistan. The CSC has been involved in this activity since its foundation since 1968 (for 50 years). Many people including scholars and public have some expectation from this dialogue activity. Off course, this activity has some reasonable impacts and influence on Pakistani society and has some future hopes in this field, positive or negative. When we deeply analyze this interfaith activity in the light of the views of Muslim-Christian scholars of Pakistan, their views are more diverse and different. Some says future of dialogue is very bright, some believe it is not bright, but nominal and some even call it a wastageof time, due to some academic and non-academic reasons.

It is also perceived, the future of inter-religious dialogue in Pakistan is encouraging due to some academic and non-academic reasons. Therefore, a reasonable number of Pakistani Muslim scholars have their reservations about modern interfaith dialogue movement, though, they do not disagree to it altogether. However, it is good sign for interfaith dialogue and relations, that all Pakistani Muslim scholars, including traditional and modern, agree to promote 
interfaith dialogue, but due to Christians' irrelevant activities in the name of dialogue, they have some serious reservations. The present interfaith dialogue cannot prove fruitful to Pakistani Muslim-Christian community, until we change its methodology and approaches. Thus, it is recommended, if we desire to see its prosperity, good future and positive impacts of interfaith dialogue on Pakistani Muslim and Christian community. We must take some bold steps for its improvement after justified evaluation. For that purpose, we can get help from impartial Muslim-Christian scholars.

\section{References \& Notes}

1. Prof. Dr. Mahmud Ahmad Ghazi: He was a well-known Islamic scholar of Pakistan. He was an author of many books related to Islamic studies. He worked as professor and president of the International Islamic university, Islamabad, Pakistan. He was known as the founder of cosmopolitan Fiqh. He worked as Minister of Religious Affairs during General Paevaiz Musharaf regime from 1999-2003. After some disagreements with General Musharaf, he left the ministry and joined the Islamic University again. He got famous from his famous Islamic lectures series Muhāzrāt Seerat. He represented Pakistan in many national and international conferences and got many awards. He died in September 2010.

2. $\quad$ http://www.oxfordislamicstudies.com/Public/focus/essay/ Accessed: 9/2/18.

3. Ghāzī, Mahmud Ahmad, Dr. Islam aur Maghrib Ta 'lluqāt (Karachi: Zawār Academy, 2009), 17.

4. Sheikh Yusuf al-Qardhāvī: He was born on 9 September 1926. He was an Egyptian Islamic theologian based in Doha, Qatar, and the chairman of the International Union of Muslim Scholars. He got influenced from Ikkhwān leader Hasan al-Bannā and Pakistani scholar Syed Maudūdī. He is best known for his program "Sharia and Life", broadcast on Al Jazeera, which has an estimated audience of 40-60 million worldwide. He published more than 120 books, including his famous The Lawful and the Prohibited in Islam and Islam: The Future Civilization. He received eight international prizes for his contributions to Islamic scholarship, and is considered one of the most influential scholars of the contemporary era.

5. http://www.memri.org/clip_transcript/en/2267.htm/21/12/2018.

6 . http//www.worldfaiths.org/international conference on Interfaith dialogue/ accessed: $10 / 2 / 18$.

7. Mufti Muhammad Taqi Usmani: He is a great Muslim scholar and writer of many value-added Islamic books, especially, on Fiqh, Islamic Economics, Tafsir and Religions etc. Presently, he is the Vice-President and Shaik-ul-Hadith of Jamia Dar-ulUloom Karachi. He is the Chairman and member of many valuable national and international Islamic Fiqh and Finance institutions. He is the chief editor of 'Alblāgh international' Magazine in Urdu and English. This interview was conducted in August 
2009 at Karachi.

8. Interview: Mufti Muhammad Taqī Usmānī (Karachi: Jamia Darul 'Ulūm, 13/7/2009).

9. Interview: Shafiq Masīh, A Protestant Priest (Karachi: Bible Society Karachi, 11/7/2009).

10. Raiz \& Naseem, "Muslim-Christian perception of Interfaith Dialogue”, The Dialogue, 16:2 (2019)79-92.

11. Mehbûb Sadā: He was a Christian scholar, theologian, poet, author and ex director of Christian Study Center, Rawalpindi. He was passed in 2011 when he was the director of the CSC. On this issue I conducted many interviews, sessions and discussions during this time (2008-11).

12. Interview: Mr. Mehbūb Sadā (Rawalpindi: Christian Study Centre, 16/8/2010).

13. Riaz Saeed, Muslim-Christian Dialogue in Pakistan, M.Phil. Theses, (Islamabad: IIU, 2011), 153.

14. Interview: Madam Romāna Bashīr (Rawalpindi: Christian Study Centre, 15/7/2010).

15. Fr. James Channan OP: He Is a Christian scholar, theologian, mystic and dialogue expert and director of peace center Lahore. He is author of many books on interfaith issues. On this issue I conducted two interviews and discussion in 2011).

16. Interview: Fr. James Channan Op (Lahore, Peace Institute, 26/7/2010).

17 Interview: Qāzī Abdul Qadīr Khāmūsh (Lahore: MCFI, 28/7/2010).

18. Dr. Muhammad Modassir Ali: He is known as the famous teacher of comparative study of religions and has worked as head of the department of the comparative study of religions at International Islamic University, Islamabad since 2011. He participated in international dialogue conferences. Currently, he is working as a research coordinator, faculty of Islamic Studies, hamad bin khalifa University, Doha Qatar since 2011.

19. Riaz, Muslim-Christian Dialogue in Pakistan, 155.

20. Dr. Muhammad Akram: He is a well-known Islamic scholar of comparative study of religions and got his doctorate degree from University of Erfurt Germany in the comparative study of religions. Presently, he is working as an associate professor and research scholar at IRI, International Islamic University. He served as head department of the comparative study of religions at the International Islamic University, Islamabad. Email Response, Dr. Muhammad Akram, e-mail: Akram.Muhammad@gmail.com/ 15/7/10). Interview, Dr. Imtiāz Zafar (Islamabad: International Islamic University, 13/7/2010). Prof. Dr. Khalid Mas' $\bar{u} d$ : He is known as a modernist Muslim scholar in Pakistan. He is ex-chairman of Islamic Ideology Council of Islamic Republic of Pakistan. He worked as Director General Islamic Research Institute, International Islamic University, Islamabad. $\mathrm{He}$ is an active member and resource person and honorary member of the Christian Study Centre on interfaith dialogue issue. He is an active supporter and promoter of Muslim-Christian dialogue in Pakistan. He showed his reservations on current situation of blasphemy laws in Pakistan.

25. Email Response, Prof. Dr. Khalid Masūd: khalid.masud@gmail.com/1/08/2010).

26. E-mail Response, Dr. Muhammad Modassir Ali: Modassir@gmail.com, 6/7/10).

27. E-mail Response, Madam Samīna Imtiāz: pead@dsl.net.pk (Islamabad: 5/7/10).

${ }_{28}^{\circ}$ Shahid, Interreligious Dialogue between Muslim and Christians, 135.

29. $\quad$ Editorial, Monthly Magazine Focus, (Multan: Pastoral Institute 2 (1988), 102-103.

30. Riaz, Muslim-Christian Dialogue in Pakistan, 155. 
31. Prof. Dr. Safir Akhtar: He is ex-professor of Islamic university Islamabad. He is a famous Islamic scholar and well versed in Christianity and an expert of interfaith dialogue. He is the founder editor of Alam-i-Islam awr Esayat (The Islamic world and Christianity). Presently, he is working at the Institute of Policy Studies Islamabad (IPS).

32. Letter Response, Prof. Dr. Safïr Akhtar (Islamabad: IPS/5/7/10).

33. Dr. Naeem Mushtaq: He is a well-known scholar of the comparative study of religions. He did his $\mathrm{Ph}$. D from abroad. He is a writer of some books on comparative study of religions. He is a resource person of the CSC. He participated in many dialogue seminars and conferences on national and international level. Presently, he is working as HR director in Islamabad Club Islamabad.

34. Interview, Dr. Naīm Mushtāq (Islamabad: Islamabad Club, 20/7/2010).

35. Riaz, Muslim-Christian Dialogue in Pakistan, 156.

36. Interview, Kāzī Jāvīd (Lahore: Peace Centre, 26/7/10).

37. Interview, Prof. Dr. Tāhir Mahmud (Islamabad: Salfiyyah Islamic University, 6/8/10).

38 Alvī, "Mukālma Bain al-Madhāhib", 21.

39. Shāhid, Religious Dialogue between Muslims and Christians, 140.

40. Hud üd Ordinance: Pakistan. Hudood Ordinance was enforced in 1979. This was an innovative experiment, merging Pakistan Penal Code offences based on Common Law Jurisprudence and criminal procedure with Hudud laws based on Hanafid jurisprudence. The religious wing welcomed it, but a considerable critical literature questioned the punishment of Rajm, ambiguity in the definitions of Zina and Zina bi alJabr.

41. Domenic Mughal, Jenifer Jevan,(ed.) Religious Minorities in Pakistan Struggle for Identity (Rawalpindi: CSC, 1996), 97.

42. Siddīqu, Christian-Muslim Dialogue in the $20^{\text {th }}$ Century, 549.

$4^{\circ}$ Interview, Prof. Dr. Muhammad Hammād Lakhvī, (Lahore: University of the Punjab /21/2/2011)

44. Islamic Da'wah in the Context of Interfaith Dialogue Scenario: Challenges \& Opportunities: This study is done by Muhammad Mutīullah Bājwah, under the supervision of Prof. Dr. Muhammad Hammād Lakhvī, in 2016 from, the University of the Punjab, Lahore.

45. Shāhid, Religious Dialogue between Muslims and Christians, 139

$46 . \quad$ Brog, "Islam in Europe", 443.

47. Safīr Akhtar,"'Ulamā e Baarīsaghīr aur Mutāla Masīhīyyat”, 'Ālame Islam aur 'Esāyat 5:1 (1995), 16-19.

48. Alvī, "Mukālma Bain al-Madhāhib", 35

49. Deyandan Francis, (ed.), New Approaches to Interfaith Dialogue (Sweden: The Church of Sweden Mission, 1972), 82.

50. Smith, Jane Idleman, Muslim-Christians and the Challenges of interfaith Dialogue (Oxford: Oxford University Press, 2007), 83.

51. Lochhead, David, The Dialogical Imperative (New York: Orbis Publishers, 1988), 64.

52 Terry Muck, A New Testament for Interfaith Dialogue (USA: Theological Society, 1993), 15.

53. http://www.watchman.org/articles/other-religious-topics/interreligiousdialogue/22/12/18.

54. Interview: Prof. Muhammad Modassir Ali (Islamabad: International Islamic 
University, 30/9/10).

55. Email Response, Dr. Muhammad Mutīullah Bājwah, e-mail: muteebahwah@gmail.com/22/12/2016.

56. Griffith, Paul, An Apology for Apologetics (New York: Orbis Publishers, 1991), 17.

57. https://www.memri.org//al-qaradhawi-muslim-christian/ Accessed: 24/12/18/.

58. Millen Markov, "The Meeting of Byzantium with Islam: Conflicting Positions and Levels of Understanding", Christianity and Culture, 68 (2012), 97-110.

59. Zia, Miraj al-Islam, "Christian-Muslim Interfaith Dialogue: A Study of the World Congress of Faiths", Peshawar Islamicus 6:1(2015), 1-10.

60. www.albasirah.com/ur/articles/politics/112-alam-e-islam/ Accessed: 10/12/18.

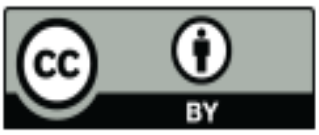

@ 2017 by the author, Licensee University of Chitral, Journal of Religious Studies. This article is an open access article distributed under the terms and conditions of the Creative Commons Attribution (CC BY) (http://creativecommons.org/licenses/by/4.0/). 